\title{
Energy and Exergy Analyses of the Danish Industry Sector
}

\author{
Bühler, Fabian; Nguyen, Tuong-Van; Elmegaard, Brian
}

Published in:

Applied Energy

Link to article, DOI:

10.1016/j.apenergy.2016.02.072

Publication date:

2016

Document Version

Peer reviewed version

Link back to DTU Orbit

Citation (APA):

Bühler, F., Nguyen, T-V., \& Elmegaard, B. (2016). Energy and Exergy Analyses of the Danish Industry Sector. Applied Energy, 184, 1447-1459. https://doi.org/10.1016/j.apenergy.2016.02.072

\section{General rights}

Copyright and moral rights for the publications made accessible in the public portal are retained by the authors and/or other copyright owners and it is a condition of accessing publications that users recognise and abide by the legal requirements associated with these rights.

- Users may download and print one copy of any publication from the public portal for the purpose of private study or research.

- You may not further distribute the material or use it for any profit-making activity or commercial gain

- You may freely distribute the URL identifying the publication in the public portal

If you believe that this document breaches copyright please contact us providing details, and we will remove access to the work immediately and investigate your claim. 


\title{
Energy and Exergy Analyses of the Danish Industry Sector
}

\author{
Fabian Bühler ${ }^{\mathrm{a}, *}$, Tuong-Van Nguyen ${ }^{\mathrm{a}}$, Brian Elmegaard ${ }^{\mathrm{a}}$ \\ ${ }^{a}$ Technical University of Denmark, Department of Mechanical Engineering, Nils Koppels \\ Allé, Building 403, 2800 Kgs. Lyngby, Denmark
}

\begin{abstract}
A detailed analysis of the Danish industry is presented in this paper using the energy and exergy methods. For the 22 most energy-intensive process industries, which represent about $80 \%$ of the total primary energy use of the industrial sector, detailed end-use models were created and analysed with data for the years 2006 and 2012. The sectoral energy and exergy losses, as well as the exergy destruction, were further established to quantify the potential for recovering and valorising heat otherwise lost. By also considering transformation processes occurring in the utility sector, the impact of using electricity and district heat in the industry is shown. The exergy efficiencies for each process industry were found to be in the range of $12 \%$ to $56 \%$ in 2012 . However variations in the efficiencies within the sectors for individual process industries occur, underlining the need for detailed analyses. The exergy losses amounted to $3800 \mathrm{TJ}$ for the same year. Meanwhile, the complete exergy losses, including the central production of heat and power, exceeded 8700 TJ. This analysis illustrates for the case study of Denmark how waste heat recovery potentials in the industrial sectors are found, by determining the sectors losses and exergy destruction. In addition the importance of applying a system analysis is shown, which corrects the site efficiencies for electricity and district heating use. The use of 22 industries, further highlights differences amongst industries belonging to the same sector.
\end{abstract}

Keywords: exergy analysis, energy analysis, system exergy, industrial sector, utility sector, Denmark

\section{Introduction}

With an increasing awareness of the environmental impacts and practical limitations associated with the traditional fossil energy carriers, many countries

\footnotetext{
*Principal corresponding author. Tel.: +45 254102

Email address: fabuhl@mek.dtu.dk (Fabian Bühler)
} 


\begin{tabular}{|c|c|c|c|}
\hline \multicolumn{4}{|c|}{ Nomenclature } \\
\hline$T$ & Temperature, ${ }^{\circ} \mathrm{C}$ & \multicolumn{2}{|c|}{ Greek letters } \\
\hline$\dot{E}$ & Exergy rate, $\mathrm{W}$ & $\eta$ & Energy efficiency, - \\
\hline$\dot{H}$ & Enthalpy rate, $\mathrm{W}$ & $\mu$ & Chemical potential,-- \\
\hline$\dot{Q}$ & Heat rate, $\mathrm{W}$ & $\phi$ & Chemical exergy to LHV ratio, - \\
\hline$\dot{W}$ & Power, W & $\psi$ & Exergy efficiency, - \\
\hline$\dot{m}$ & Mass flow rate, $\mathrm{kg} / \mathrm{s}$ & \multicolumn{2}{|c|}{ Superscripts } \\
\hline$e$ & Specific exergy, $\mathrm{J} / \mathrm{kg}$ & $\mathrm{ch}$ & Chemical \\
\hline$h$ & Specific enthalpy, $\mathrm{J} / \mathrm{kg}$ & $\mathrm{ph}$ & Physical \\
\hline$i$ & $\mathrm{i}^{\text {th }}$ fuel & $\mathrm{Q}$ & Heat transfer \\
\hline$j$ & $\mathrm{j}^{\text {th }}$ process & sys & system \\
\hline$p$ & Pressure, $\mathrm{Pa}$ & $\mathrm{W}$ & Work transfer \\
\hline$s$ & Specific entropy, J/kgK & 0 & Environmental state \\
\hline$x$ & Molar fraction, - & 00 & Dead state \\
\hline \multicolumn{2}{|c|}{ Abbreviations } & $\mathrm{d}$ & Destruction \\
\hline $\mathrm{CHP}$ & Combined heat and power & $\mathrm{e}$ & Electric \\
\hline DH & District heat & $\mathrm{f}$ & Fuel \\
\hline LHV & Lower heating value, $\mathrm{J} / \mathrm{kg}$ & in & Inflow \\
\hline $\mathrm{SC}$ & Self-consumption & $\mathrm{k}$ & Thermal stream \\
\hline SiEN & Site energy efficiency, - & $\mathrm{L}$ & Loss \\
\hline SiEX & Site exergy efficiency, - & out & Outflow \\
\hline SyEN & System energy efficiency, - & $\mathrm{P}$ & Product \\
\hline SyEX & System exergy efficiency, - & $\mathrm{pr}$ & Process \\
\hline
\end{tabular}

aim to increase the efficiency of the processes using energy, while shifting to more sustainable energy sources. It is thus crucial to understand and analyse the systems where resources and energy are consumed and depleted, in order to plan and steer future developments. The industrial sector is one of the systems consuming the largest quantities of resources. Denmark has had a focus on energy efficiency since the first oil crisis in 1973 and the country has implemented policies for the industrial sector, particularly at the beginning of 1990's. Currently, energy efficiency obligations for the Danish energy distribution companies affect all end-consumer sectors, and, since 2013, an investment subsidy scheme promotes the use of renewable energy and the implementation of energy efficiency measures for industrial processes [Danish Energy Agency,2014a]. 
The application of energy-based methods is useful for tracking the energy flows within a given system and visualising the conversion from one form of energy to another. However, such tools present inherent limitations, as they cannot be used for assessing the performance losses within a given system. Unlike energy, exergy is destroyed by thermodynamic irreversibilities and this concept is used in this work to account for the quality of energy: it thereby better describes the inefficiencies and waste heat recovery potentials of the system. Hammond[2007] gives a comparison and method on using thermodynamic methods for the analysis of industrial energy-systems. Further, Hammond and Norman[2014] investigate the technically recoverable surplus heat and Ammar et al.[2012] discusses low grade heat capture from the UK industry, both applying exergy methods and analysing various industries.

There have been a number of studies conducted analysing the energy and exergy efficiency of a country. The most notable are the ones conducted for the United States [Reistad,1975], Canada [Rosen,1992], Sweden [Wall,1997], United Kingdom [Hammond and Stapleton,2001], Turkey [Utlu and Hepbasli,2004], Saudi Arabia [Dincer et al.,2004a] and Norway [Ertesvåg,2005]. These works demonstrate the usefulness of thermodynamic methods for depicting opportunities for better energy management, and they show significant potentials for improvements in the countries and different sectors. A review of the studies and methodologies was performed by Utlu and Hepbasli [Hepbasli,2005;Utlu and Hepbasli,2007]. They suggest a formalisation of the methods for modelling the sectoral energy and exergy utilisation, starting from the listing of all energy and exergy inputs and outputs, then with a sub-grouping of the sectors into utility, industrial, commercial, residential \& transportation, and a further splitting into each end-user. Other works focus on specific sectors, such as Dincer et al.[2004b] and Liu et al.[2014] on the residential sector of Saudi Arabia and China, while the one of Motasemi et al.[2014] deals with the case of the transport sector of Canada. The studies that are the most relevant to the present work may be the ones of Al-Ghandoor et al.[2010], who apply energy and exergy methods, as well as Sanaei et al.[2012], Dincer et al.[2003] and Oladiran and Meyer[2007], all focusing on the industrial sector of a country. They establish and compare the efficiencies of several industrial sectors for the cases of United States, Iran, Saudi Arabia and South Africa. These works, however, do not distinguish between the destroyed exergy due to irreversibilities and the exergy lost to the environment. In addition, great differences in the level of detail, e.g. the number of considered processes and the number of industries accumulated in sectors, exist amongst them.

The present work aims at addressing these lacks by increasing the level of details and determining the excess heat temperatures of the processes. It is the first detailed exergy analysis of the industry sector in Denmark, using energy and exergy methods in continuation of the previous work of Bühler et al.[2015]. This analysis builds on 22 industries with up to 10 thermal and 13 electric end-use categories, and divides thermal losses into conversion and direct losses. The inefficiencies are split into their exergy destruction and losses part, based on the excess heat temperatures. This approach allows therefore for a better 
quantification of the real thermodynamic recovery potential, compared to relying exclusively on the energy or exergy efficiency indicators. A more complete comparison of the industries is carried out, which is made possible by the inclusion of the inefficiencies in the utility sector. The present results are finally compared to the previous studies in this field, which focus only on fewer main sectors in their analysis, and the findings show therefore the additional insights derived from a more thorough approach.

Section 2 presents the methods and approach of this work. Twenty-two industrial sectors, representing $79 \%$ of the energy used in the Danish industry, are assessed in order to determine the energy and exergy efficiencies, as well as the destroyed and lost exergy. The efficiencies are calculated based on the scientific and technical literature available for Denmark and on complementary assessments. Section 3 describes the main results, which (i) show where in the Danish industry the lowest efficiencies and highest losses occur, (ii) document the changes in the industrial sector over the last years, and (iii) pinpoint the industries with potential for the recovering energy and exergy. As proposed and formalised by Soundararajan et al.[2014], the results in exergy terms will be presented in a Sankey diagram. In a further step, Section 4 discusses the validity and relevance of the results, which are compared to similar studies performed in this field, while Section 5 concludes the present study and findings.

\section{Methods}

\subsection{Case Study}

Industrial Sector. The industry sector in Denmark consists of several subsectors, without being dominated by single types of industries. The total energy input to the industry sector, excluding the extraction of oil and gas resources, agriculture and the service sector, amounted to $112 \mathrm{PJ}$ in 2012, which is a reduction of $12 \%$ compared to 2006 [Statistics Denmark,2015]. In this study, the 22 most energy intense industries were selected, which together represented $79 \%$ of the energy consumption of the industrial sector in 2012 [Statistics Denmark,2015]. For each of these sectors (Figure 1), the energy input from 16 different fuel types (e.g. oil, natural gas, biogas), electricity, district heat and heat pumps is available. In addition, previous publications by the Danish Energy Agency[2008a] provide the distribution of fuels and district heating amongst 10 process categories, such as distillation, heating, evaporation, drying and conversion and transmission losses. The electricity input is distributed between 13 final processes. We do not consider the end-consumers for transportation within the industry sector.

Utility Sector. The utility sector (Figure 2) is also taken into account. In Denmark, electricity from thermal power plants is to a large extend produced in combined heat and power plants (CHP), using primarily coal, natural gas and biomass. Furthermore, a share of $29 \%$ of the net electricity produced originated from wind power and $15 \%$ was from net imports in 2012 from the neighbouring 


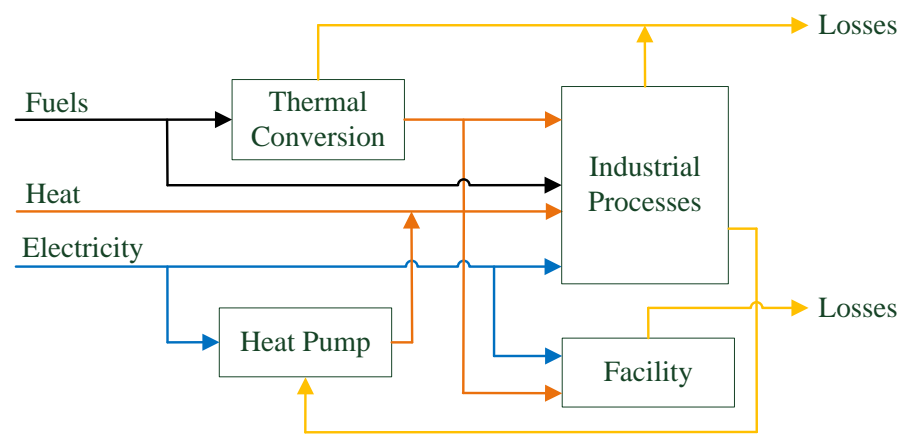

Figure 1: Processes and energy flows within an industry sector.

countries (e.g. Germany, Sweden and Norway) [Danish Energy Agency,2014b]. Almost $74 \%$ of the district heat is produced in CHP units and the remaining part in heating units. The data from the Danish Energy Agency[2014b,2008b] also gives information on the self-consumption of the power plants, as well as on the distribution and transmission losses.

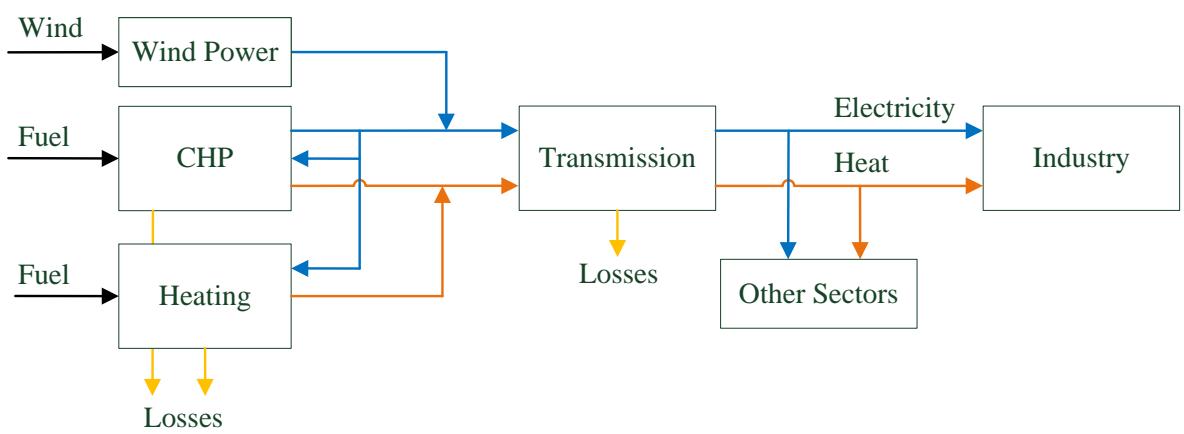

Figure 2: Processes and energy flows within the utility sector.

\subsection{Theoretical background}

\subsubsection{Energy Balance}

As stated by the 1st law of thermodynamics, energy may be stored, transformed from one form to another (e.g. from mechanical to electrical), but can neither be created nor destroyed. For an open system, energy can be transferred in- and out of the system under study with streams of matter, heat and work. We do not consider changes in kinetic (velocities) and potential (heights) energies, which implies that the energy balance in steady-state conditions, on a rate form, is as follows:

$$
\sum_{\text {in }} \dot{H}_{\text {in }}-\sum_{\text {out }} \dot{H}_{\text {out }}+\sum_{k} \dot{Q}_{k}-\dot{W}=0
$$




$$
\sum_{\text {in }} \dot{m}_{\text {in }} h_{\text {in }}-\sum_{\text {out }} \dot{m}_{\text {out }} h_{\text {out }}+\sum_{k} \dot{Q}_{k}-\dot{W}=0
$$

where $\dot{H}$ denotes the energy associated with a stream of matter; $h$ the specific enthalpy of a material stream; $\dot{m}$ the mass flow rate of the corresponding stream; the subscripts in and out indicate in- and outflowing streams; $\dot{Q}$ and $\dot{W}$ the heat and work rates exchanged with the surroundings.

The use of an energy analysis is relevant for tracking the energy flows and the transformation of one form of energy to another across different systems.

\subsubsection{Exergy Accounting}

Unlike energy, exergy can be destroyed and accounts for the use of additional primary energy induced by the systems imperfections. It can be defined as the maximum useful work as the system is brought into complete thermodynamic equilibrium with the thermodynamic environment, while the system interacts with it only. A system in thermal and mechanical equilibrium (same temperature and pressure) with the environment is termed environmental state or restricted dead state [Bejan et al.,1996], while it is in dead state if also in chemical equilibrium (same chemical species). This thermodynamic concept builds on the first and second laws of thermodynamics, reflecting that all transformations are irreversible in nature and generate entropy. The exergy destruction is defined as the difference between the exergy inflowing and outflowing the system under study, and can thus be derived from the previous relations as:

$$
\begin{gathered}
\sum_{\text {in }} \dot{E}_{\text {in }}-\sum_{\text {out }} \dot{E}_{\text {out }}=\dot{E}_{d} \\
\sum_{\text {in }} \dot{m}_{\text {in }} e_{\text {in }}-\sum_{\text {out }} \dot{m}_{\text {out }} e_{\text {out }}+\sum_{k} \dot{E}_{k}^{Q}-\dot{E}^{W}=\dot{E}_{d}
\end{gathered}
$$

where $\dot{E}$ denotes the exergy associated with a stream of matter, heat or work; $e$ the specific exergy of a material stream; $\dot{E}_{k}^{Q}$ and $\dot{E}^{W}$ the heat and work exergy rates exchanged with the surroundings; $\dot{E}_{d}$ the destroyed exergy. The exergy losses $\dot{E}_{L}$ are included in the exergy stream out of the system.

\subsubsection{Flow Exergy}

The specific exergy of a flowing stream of matter consist of physical, chemical, kinetic and potential components. Excluding the kinetic and potential components, the specific exergy can be expressed as follows:

$$
e=\left[\left(h-h_{0}\right)-T_{0}\left(s-s_{0}\right)\right]+\left[\sum_{j}\left(\mu_{j, 0}-\mu_{j, 00}\right) x_{j}\right]
$$

The first term of Eq.5 describes the physical exergy, which is the maximum useful work that can be extracted from the stream when brought to environmental conditions (temperature and pressure). The second part, the chemical exergy, is the maximum available work that can be extracted from the stream 
when brought from the environmental state (denoted with the subscript 0 ) to the dead state (denoted with the subscript 00). The chemical exergy for the fuels used in the industrial sector was calculated based on their chemical composition in Denmark, where applicable. For liquid and solid fuels, the approach by Szargut[1989] and for gaseous fuels by Bejan et al.[1996] was used. The ratio of the specific chemical exergy $\mathrm{e}^{\mathrm{ch}}$ to the lower heating value of the fuel LHV, $\Phi$, is given for the different fuels in Table 1 and can be calculated with Eq.6.

$$
e^{\mathrm{ch}}=\phi_{\mathrm{f}} L H V
$$

The exergy associated with work is equal to its energy, whilst the exergy trans-

Table 1: Properties of fuels used in the industry sector at reference conditions with the $L H V$ based on Statistics Denmark[2015].

\begin{tabular}{lrrr}
\hline Fuel & $\begin{array}{r}L H V \\
(\mathrm{MJ} / \mathrm{kg})\end{array}$ & $\begin{array}{r}\phi \\
(-)\end{array}$ & $\begin{array}{r}e^{\mathrm{ch}} \\
(\mathrm{MJ} / \mathrm{kg})\end{array}$ \\
\hline Refinery Gas & 52.0 & 1.161 & 60.4 \\
LPG & 46.0 & 1.056 & 48.6 \\
Gasoline & 43.8 & 1.071 & 46.9 \\
Fuel Oil & 42.7 & 1.067 & 45.6 \\
Diesel & 42.7 & 1.068 & 45.6 \\
Heavy Fuel Oil & 40.7 & 1.066 & 43.3 \\
Petroleum coke & 31.4 & 1.048 & 32.9 \\
Natural Gas & 48.0 & 1.065 & 51.2 \\
Coal & 24.2 & 1.076 & 26.1 \\
Coke & 29.3 & 1.048 & 30.7 \\
Waste & 10.5 & 1.152 & 12.1 \\
Wood Chips & 9.3 & 1.193 & 11.1 \\
Wood Pellets & 17.5 & 1.072 & 18.8 \\
Straw & 14.9 & 1.084 & 16.2 \\
Biogas & 19.8 & 1.041 & 33.7 \\
Bio Oil & 36.7 & 1.114 & 40.9 \\
\hline
\end{tabular}

ferred with heat depends on the heat transfer and dead state temperatures (in this case, above ambient conditions).

$$
\dot{E}_{k}^{Q}=\left(1-\frac{T_{0}}{T_{k}}\right) \dot{Q}_{k}
$$

The dead state conditions are selected as a temperature of $15^{\circ} \mathrm{C}$, a pressure of 1.013 bar, and with the reference chemical environment of Szargut [Szargut,1989]. The environmental temperature is taken as the average conditions in Denmark. It has an impact on the calculations of the chemical energy and exergy of fuels, which can vary in a range of $+/-0.5 \%$ per $10^{\circ} \mathrm{C}$ change for the fuels investigated in this study Ertesvåg[2007]. A varying dead state temperature in the range of $0{ }^{\circ} \mathrm{C}$ to $25^{\circ} \mathrm{C}$ showed no significant impact on exergy efficiencies in a sectorial analysis [Utlu and Hepbasli,2008]. 


\subsubsection{Energy and exergy efficiency}

The energy $(\eta)$ and exergy $(\Psi)$ efficiency of the system is defined below, as the sum of energy or exergy in the product, divided by the total energy or exergy input to the system.

$$
\begin{gathered}
\eta=\frac{\text { energy in product }}{\text { total energy input }} \\
\Psi=\frac{\text { exergy in product }}{\text { total exergy input }}
\end{gathered}
$$

The efficiencies in this work are divided into site and system efficiencies, the latter including the utility processes. From Figure 3 the applied system boundaries can be seen, where the system efficiency includes losses from the utility system. The efficiencies are further subdivided on the site level based on the end-use. Four end-use categories are established: thermal and machine processes, as well as thermal and electric facility use. In the following sections the equations for the efficiencies will be shown in more detail.

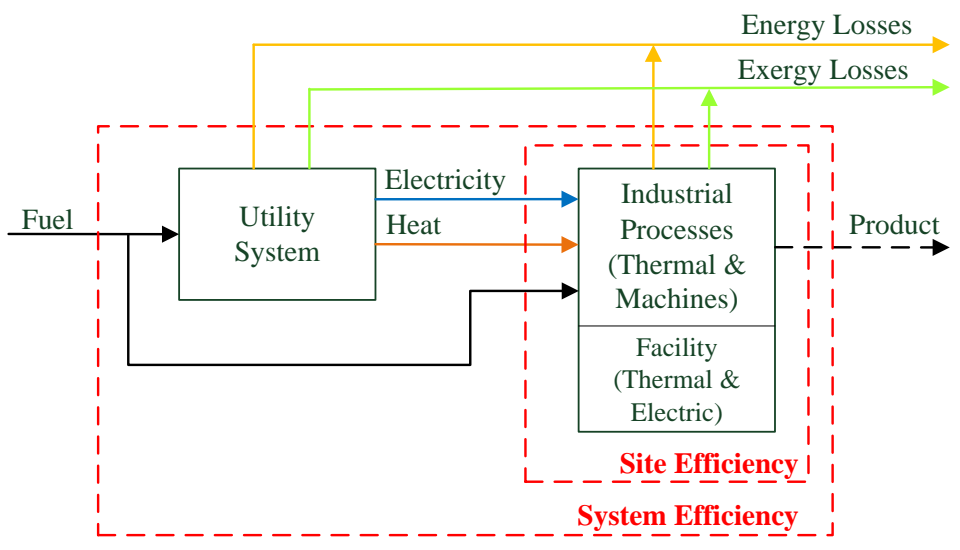

Figure 3: System boundaries for site and system efficiency.

\subsection{Application}

In the following, the applied techniques are explained for the case of the industrial and utility sectors of Denmark, and the sources of losses and exergy destruction are pointed out.

\subsubsection{Industrial Sector}

Global approach. Figure 4 shows the overall approach for the determination of energy and exergy losses and the exergy destructions for the industry sector. For each of the 22 industry sectors, the fuel consumption for all individual process categories is distributed amongst three temperature levels and for each level, the mean process temperature is determined. The process information used 
to establish this distribution and the mean temperatures originates from several sources, with the main ones being the Danish Energy Agency[2008a,2015], the European Commission[2015], the Graz University of Technology[2015], and the U.S. Environmental Protection Agency[2015]. The energy losses derive from (i) the conversion and transmission losses, and (ii) the direct use of fuels and electricity. The former are determined by the Danish Energy Agency[2008a,2015]. They account for the conversion of fuels to a secondary energy carrier, which is supplied to the processes. Transmission losses occur primarily in the steam and hot water distribution systems. The magnitude of these losses differs from sector to sector: it is impacted by the process type and the share of room heating within the total heating demand. The heat rejected to the environment (waste heat) has a temperature of up to $260{ }^{\circ} \mathrm{C}$. It does, however, not exceed $150{ }^{\circ} \mathrm{C}$ for about $50 \%$ (45\% in 2006) of the sources, since waste heat recovery equipment is installed [Viegand Maagøe A/S,2013;U.S. Department of Energy,2008]. The second type of energy losses results from the direct use of fuels and electricity in the process and thermal losses of high-temperature processes. Examples of these processes are drying of gravel in direct-fired dryers or melting of metals in furnaces, where the energy used within the sector is directly utilised in the process. The efficiency for direct process heating is dependent on the process temperature and is presented in Table 2. The applied efficiencies are based on Rosen[1992] and Dincer et al.[2003] but are adjusted to Denmark. For temperatures below $120^{\circ} \mathrm{C}$, the fuel heating efficiency is $100 \%$, as this heat is almost fully supplied by secondary energy carriers for which the conversion and transmission losses are applied. The values of the waste heat temperatures for the losses in the direct conversion and high temperature components are based on literature data [U.S. Department of Energy,2008;Technical University of Denmark,2015]. For electricity use in machinery and the facilities (excl. pro-

Table 2: Energy efficiency for heating with fuels and electricity used in the industry sector.

\begin{tabular}{rccc}
\hline & Range & \multicolumn{2}{c}{ Direct Heating Efficiency } \\
Electrical & Fuel \\
\hline Low & $\leq 120$ & $(\%)$ & $(\%)$ \\
Medium & $120-380$ & 100 & 100 \\
High & $\geq 380$ & 75 & 85 \\
\hline
\end{tabular}

cess and room heating), efficiencies for the conversion were taken from Dansk Energi[2015], assuming large-scale units with an average load rate of between $70 \%$ to $80 \%$.

Process heat and room heating. First, the thermal energy used for the processes $\dot{Q}_{p r}$ is determined based on the energy distribution for the different processes. The losses for fuel conversion are subtracted, and for the direct use of fuels and electricity, the efficiency is defined based on the temperatures as shown in Table 


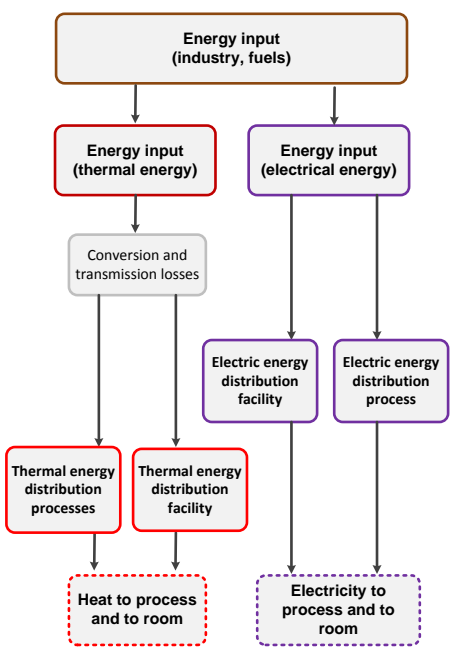

(a) Energy Analysis

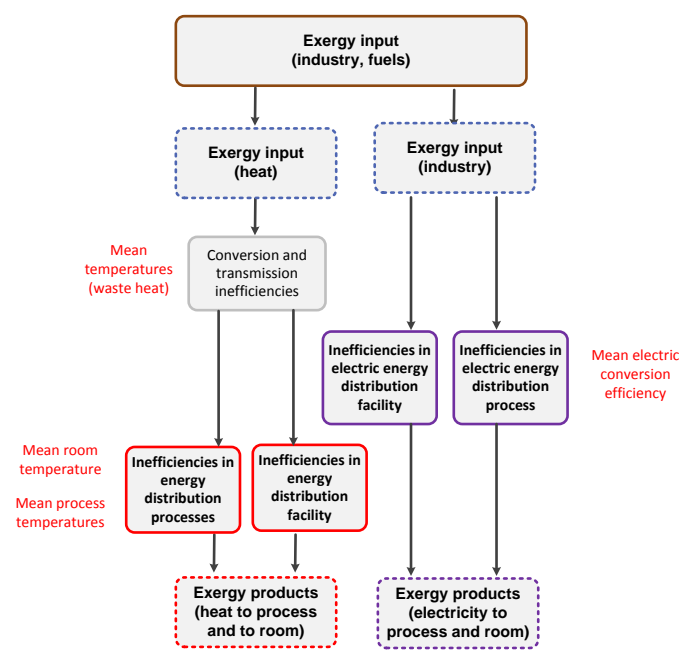

(b) Exergy Analysis

Figure 4: Flow chart of the methodology for the analysis of the industrial sector with the fuels and considered processes.

2.

$$
\sum_{i, j} \dot{m}_{f i, j}(\mathrm{LHV})_{i}=\sum_{i, j} \dot{Q}_{p r i, j}+\sum_{i, j} \dot{Q}_{L i, j}
$$

The exergy in the product $\dot{E}_{P}^{Q}$ is found with equation (11) based on the average process temperature $T_{p r}$ and the thermal energy $\dot{Q}_{P}$ of the product. The exergy losses $\dot{E}_{L}^{Q}$ are found in the same manner as a function of the mean waste heat temperature $T_{W}$ and the thermal energy loss $\dot{Q}_{l}$. The rate of exergy destruction $\dot{E}_{d}$ of each process and fuel is found by subtracting the exergy in the product and losses from the total exergy into the process $\dot{E}_{f}$.

$$
\begin{aligned}
& \dot{E}_{P}^{Q}=\left(1-\frac{T_{0}}{T_{p r}}\right) \dot{Q}_{P} \\
& \dot{E}_{L}^{Q}=\left(1-\frac{T_{0}}{T_{L}}\right) \dot{Q}_{L} \\
& \dot{E}_{d}=\dot{E}_{f}-\dot{E}_{P}^{Q}-\dot{E}_{L}^{Q}
\end{aligned}
$$

Process and facility electric use. The use of electricity in processes and facility is based on the electric efficiency of the units $\eta_{e}$. The useful work $\dot{W}$ retrieved from the electric energy in $\dot{W}_{e}$ can be calculated using Eq. 14. As mechanical and electric work are equal to the exergy of work and electricity, Eq. 14 also applies to the exergy calculations.

$$
\dot{W}=\eta_{e} \dot{W}_{e}
$$


Efficiency of each industry sector. For each sector, the process heating efficiency $\eta_{p r, h}$ is defined as the ratio of the sum of the thermal energy in the products and the total energy input to the thermal processes in the sector.

$$
\eta_{p r, h}=\left(\frac{\sum_{j} \dot{Q}_{P, j}}{\sum_{i} \dot{m}_{f, i}(\mathrm{LHV})_{i}}\right)
$$

where $\dot{Q}_{p, j}$ denotes the heat transfer associated with the process $j ; \dot{m}_{f, i}$ the mass flowrate of the fuel $i$; $(\mathrm{LHV})_{i}$ is the lower heating value of the fuel $i$.

Similar to the energy efficiency, the exergy efficiency for process heating $\Psi_{p r, h}$ is defined as:

$$
\Psi_{p r, h}=\left(\frac{\sum_{j} \dot{E}_{j}^{Q_{P}}}{\sum_{i} \dot{m}_{f, i} \phi_{i}(\mathrm{LHV})_{i}}\right)
$$

where $\dot{E}_{j}^{Q_{P}}$ denotes the exergy transfer associated with heat transfer $Q_{P, j}$ of the process $j ; \phi_{i}$ is the fuel to exergy ratio of the fuel $i$.

For the electric heating efficiency, the sum of heat transfer for the processes is divided by the electric work into the system. For the exergetic electric heating efficiency, the exergy transfer associated with the heat transfer is used. The efficiency for the use of mechanical work in the processes is derived with the following equation, where the energy $\left(\eta_{p r, e}\right)$ and exergy $\left(\Psi_{p r, e}\right)$ efficiency are equal.

$$
\eta_{p r, e}=\Psi_{p r, e}=\left(\frac{\sum_{j} \dot{W}_{j}}{\sum_{j} \dot{W}_{e, j}}\right)
$$

where $\dot{W}_{j}$ denotes the work of the process $j ; \dot{W}_{e, j}$ is the electrical work into the process $j$.

For the facilities, the efficiencies are found by analogy to the process efficiencies, with the energy $\left(\eta_{f a, h}\right)$ and exergy $\left(\Psi_{f a, h}\right)$ efficiency for the heating processes within the facility, as well as for the electricity use $\left(\eta_{f a, e}\right.$ and $\left.\Psi_{f a, e}\right)$.

\subsubsection{Utility Sector}

Global approach. In Figure 5 the approach for the analysis of the utility sector is shown. There are three sources of energy losses, namely conversion, transmission and self-consumption. When considering exergy, losses only occur in the form of waste heat from the power plants flue gas since the internal energy losses are accounted as exergy destruction. The average temperature of the flue-gases is taken as $150{ }^{\circ} \mathrm{C}$ [Nag,2002] and is assumed constant, although it changes in practice with the fuel used in the combustion process. The waste heat discharged through the condenser of steam power plants is neglected as it is rejected at low to very low temperatures (between $30^{\circ} \mathrm{C}$ and $100^{\circ} \mathrm{C}$ ). Exergy is destroyed in the conversion of the fuels to electricity and district heat, the off-gases from the power plants, and with the transmission losses and selfconsumption. The transmission losses of the district heating distribution pipes are assumed to be close to the dead state temperature, implying that very little 
exergy can be recovered. In the case of electricity from wind energy, only the transmission losses are taken into account. Import and export of electric energy are not considered in this study, as they balance on a long term basis. For each utility system, the required fuel input for the generation of one unit electricity and district heat is found. The fuel allocation, in the case of combined heat and power production, is done based on the product distribution. The allocation of the exergy destruction and losses to the final exergy products delivered to the industry follows the same reasoning, with a separation between the destruction and losses. The aim of the analysis of the utility sector is to find the system energy and exergy losses, as well as the exergy destruction, for electricity and district heat. This approach is similar to the one of Szargut et al.[2002] for the cumulative consumption of non-renewable exergy in manufacturing and of Granovskii et al.[2007] for the exergetic life cycle assessment, applied to hydrogen production from renewable sources. Further, Cornelissen and Hirs[2002] showed the value of using exergetic life cycle assessment at the example of waste wood treatment and Stougie and Kooi[2012] evaluated the relation between exergy losses and environmental. Our analysis, however, takes only energy and exergy transformations of the fuels, within in the utility and industrial sector, into account.

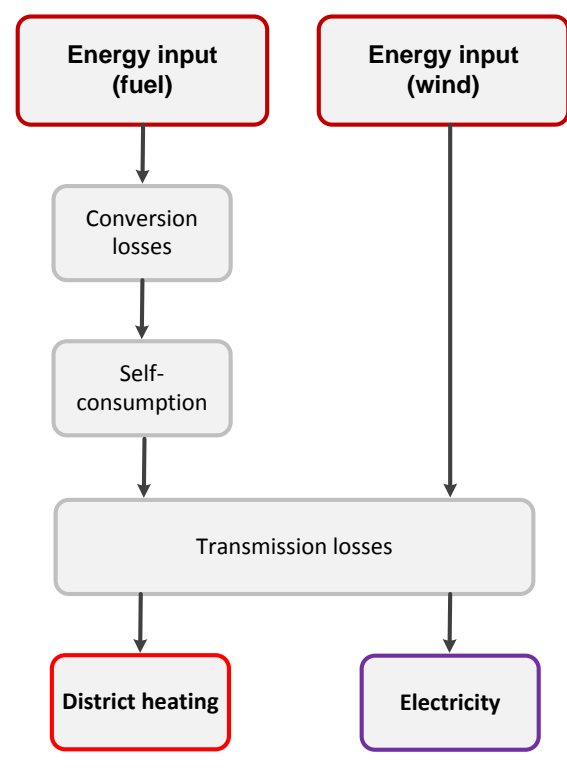

(a) Energy Analysis

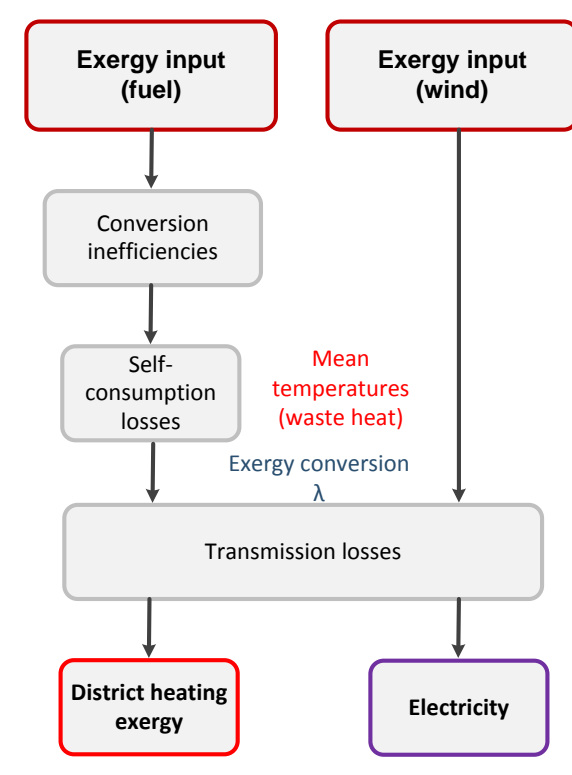

(b) Exergy Analysis

Figure 5: Flow chart of the methodology for the analysis of the utility sector with the fuels and considered processes. 
Electricity and district heat from the utility sector. For combined heat and power plants, the energy balance used is as follows:

$$
\sum_{i} \dot{m}_{f, i}(\mathrm{LHV})_{i}+\dot{W}_{e, \mathrm{SC}}=\dot{W}_{e}+\dot{Q}_{\mathrm{DH}}+\dot{Q}_{L}
$$

The reformulation of the energy balance is done for the losses similar to the thermal processes within the industry. The exergy destruction within the power plant is found as the difference between the product and loss exergy content and the exergy into the system.

System energy and exergy efficiencies. The system energy $\left(\eta_{p r, h}^{\mathrm{sys}}\right)$ and exergy $\left(\Psi_{p r, h}^{\mathrm{sys}}\right)$ efficiencies account for the generation and transmission losses associated with the production of electricity and district heat. They are defined as the sum of exergy or heat contained in the product, divided by the sum of the direct energy or exergy input at the thermal site and the indirect input at the utility sector for the supply of district heat and power. The efficiencies can be expressed as follows:

$$
\begin{gathered}
\eta_{p r, h}^{\mathrm{sys}}=\frac{\sum_{j} \dot{Q}_{P, j}}{\sum_{i} \dot{m}_{f, i}(\mathrm{LHV})_{i}+\sum_{n} \dot{m}_{f, n i}(\mathrm{LHV})_{n}} \\
\Psi_{p r, h}^{\mathrm{sys}}=\frac{\sum_{j} \dot{E}_{j}^{Q_{P}}}{\sum_{i} \dot{m}_{f, i} \phi_{i}(\mathrm{LHV})_{i}+\sum_{n} \dot{m}_{f, n} \phi_{n}(\mathrm{LHV})_{n}}
\end{gathered}
$$

With the same approach, the efficiencies for the generation of work and heat in the facilities can be found.

\section{Results}

The results of the analysis are presented in the following. First, the industrial site analysis is shown, followed by the system analysis and the quantification of exergy losses for the year 2012. At the end, a comparison of the results with data from 2006 is performed. In Table 3, the total energy consumption of the industrial sectors is shown for the analysed years 2006 and 2012. The two industries with the highest process heating demand are the oil refineries and the production of cement. Despite the general trend that for most industries the energy input decreased between 2006 and 2012, some sectors such as the wood industry have an increase. This is partly a result of production changes and of a different sectorial distribution by Statistics Denmark (i.e. sector 15). In total, the energy consumption was reduced by $16 \%$ between 2006 and 2012 .

Site analysis of the industrial sector. The energy and exergy efficiencies for all thermal processes occurring in the industrial sectors in 2012 are shown in Figures 6 and 7, respectively. For heating processes in the facilities, high energy efficiencies are achieved, where industries using electric and district heat reach the highest ones. In exergy terms, the efficiency is the lowest for the facilities because of the low product temperatures of room heating. For the thermal use 
Table 3: Total energy use of the industries considered in 2012 and 2006 in (TJ). Distributed according to Danish Energy Agency[2008a,2015] and data from Statistics Denmark[2015].

\begin{tabular}{|c|c|c|c|c|c|c|c|}
\hline \multirow[t]{2}{*}{ No. } & \multirow{2}{*}{ Industry } & \multicolumn{2}{|c|}{ Process Heating } & \multicolumn{2}{|c|}{ Machine Drive } & \multicolumn{2}{|c|}{ Facility } \\
\hline & & 2012 & 2006 & 2012 & 2006 & 2012 & 2006 \\
\hline 1 & Gravel and stone & 2847 & 3819 & 326 & 283 & 43 & 88 \\
\hline 2 & Refined oil & 16789 & 17142 & 1020 & 742 & 66 & 46 \\
\hline 3 & Meat & 1855 & 1762 & 1094 & 1646 & 904 & 892 \\
\hline 4 & Dairy products & 3394 & 3332 & 1298 & 1001 & 776 & 595 \\
\hline 5 & Compound feed & 1158 & 1460 & 658 & 839 & 221 & 288 \\
\hline 6 & Sugar & 2725 & 3285 & 354 & 172 & 140 & 239 \\
\hline 7 & Other food products & 2403 & 3530 & 999 & 1355 & 444 & 693 \\
\hline 8 & Wood & 2706 & 2082 & 585 & 962 & 718 & 1060 \\
\hline 9 & Paper & 1770 & 2183 & 559 & 986 & 284 & 373 \\
\hline 10 & Industrial Gasses & - & - & 399 & 447 & 60 & 69 \\
\hline 11 & Enzymes & 1026 & 1191 & 875 & 1028 & 195 & 292 \\
\hline 12 & Other chemicals & 520 & 562 & 707 & 654 & 304 & 361 \\
\hline 13 & Pharmaceuticals & 1592 & 1208 & 1289 & 1146 & 264 & 1640 \\
\hline 14 & Plastic and rubber & 897 & 1737 & 965 & 1189 & 913 & 1770 \\
\hline 15 & Paint, soap etc. & 3065 & 734 & 1006 & 807 & 353 & 930 \\
\hline 16 & Cement & 9116 & 14734 & 1038 & 1703 & 52 & 85 \\
\hline 17 & Bricks & 1310 & 1334 & 119 & 134 & 14 & 15 \\
\hline 18 & Asphalt & 1343 & 1252 & 96 & 108 & 77 & 69 \\
\hline 19 & Rockwool & 1666 & 2257 & 293 & 330 & 76 & 72 \\
\hline 20 & Concrete and bricks & 2273 & 1956 & 275 & 309 & 270 & 281 \\
\hline 21 & Basic metals & 2187 & 2807 & 386 & 728 & 421 & 780 \\
\hline 22 & Metal products & 1326 & 2132 & 856 & 1129 & 1490 & 2769 \\
\hline
\end{tabular}

of energy within industrial processes, energy efficiencies above $70 \%$ are found for all sectors. Sectors with high-temperature operations and the direct use of fuels for processes, i.e. sectors within metal and building material production, have the lowest efficiencies. For those sectors, high exergy efficiencies are found, as the high temperature operations increase the exergy content in the products. Only sector 20 has a comparable low exergy efficiency, as it includes the production of concrete elements and gypsum plates, where thermal energy is required at lower temperatures. The overall exergy efficiencies range from 10 to $55 \%$ for thermal processes, excluding sector 10 (industrial gases), where no thermal processes occur in the production. The comparison of the energy and exergy efficiencies for process heating shows that exergy can be more useful. The example of room heating suggests that the process is already close to its optimum, as very high energy efficiencies, between $85 \%$ and $100 \%$, are retrieved. However, the very low exergy efficiency of room heating, below $10 \%$ for most industries, reveals that considerable improvement potentials exist. Higher exergy efficiencies can be achieved by using low exergy sources for low temperature heating processes. This could be for instance district heat or heat recovered from high temperature processes. With these measures not only the room heating, but 


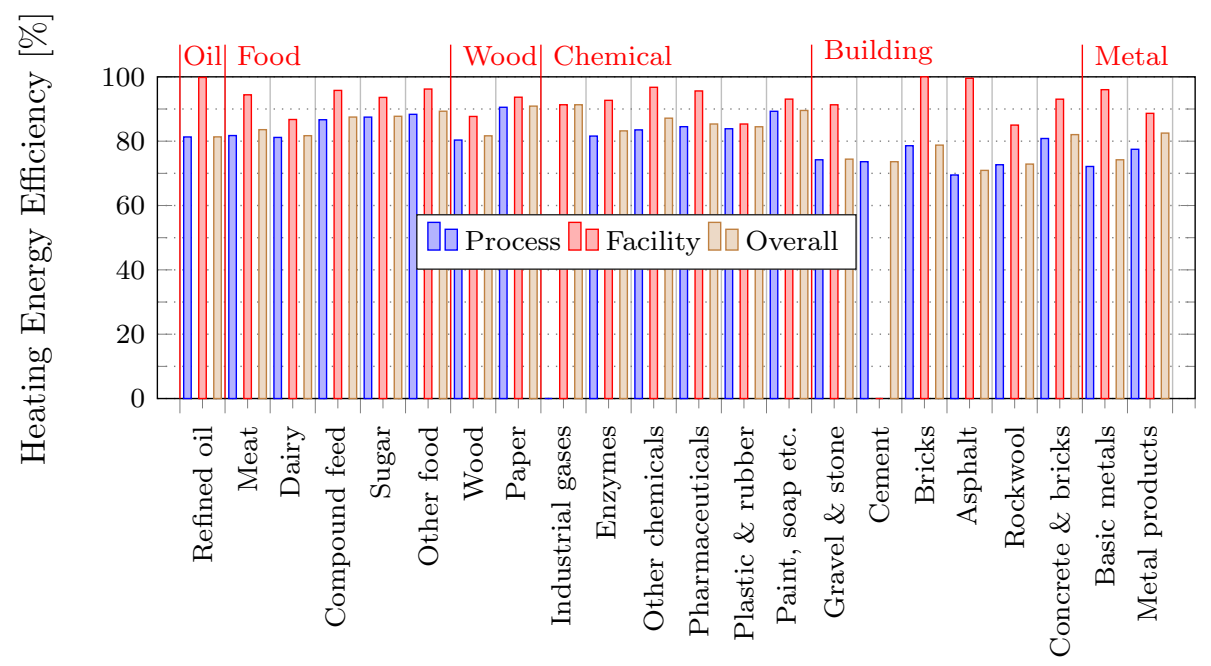

Figure 6: Energy efficiencies within the industry for thermal heating in processes, facilities and overall, as the weighted average.

also the processes can be designed more efficiently.

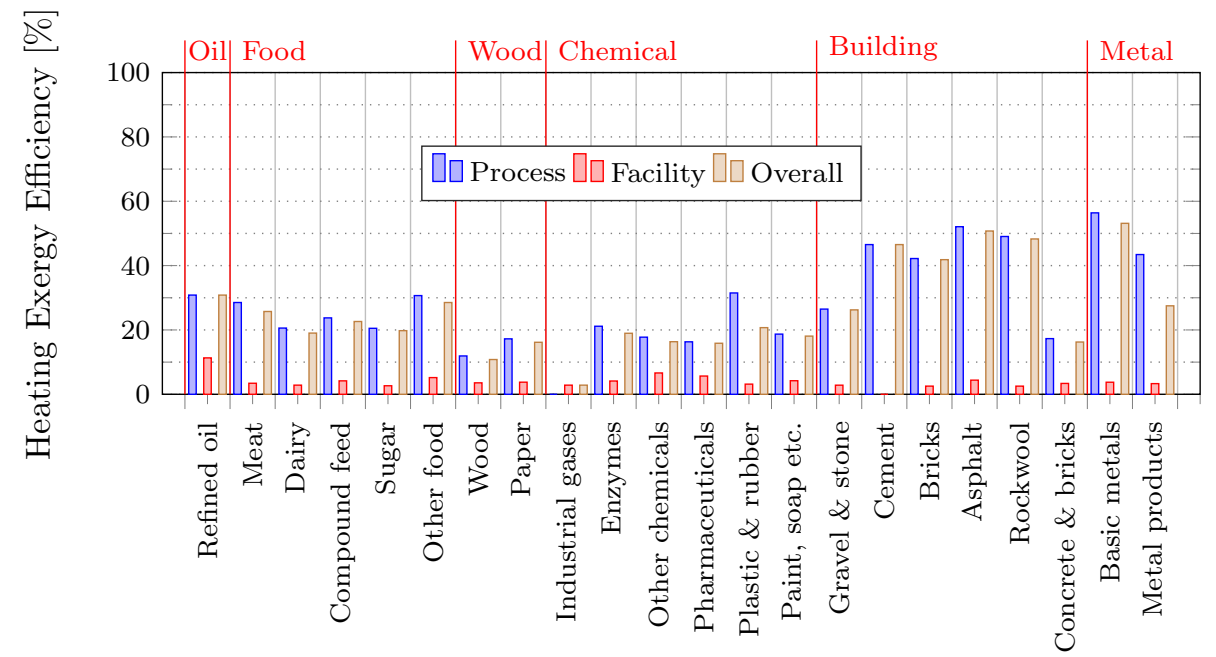

Figure 7: Exergy efficiencies within the industry for thermal heating in processes, facilities and overall, as the weighted average.

System efficiency of the industrial sector. The exergetic efficiencies, including losses of district heat and electricity occurring at the central power stations and during transmission, are shown for the total thermal and electric energy use in 
Figure 8. A comparison of the total site and the total system exergy efficiencies is done in Figure 9, where all heating and mechanical processes are included. The system exergy efficiency for electric processes is nearly constant over all the sectors, as it is a direct function of the electric energy efficiency. However, the thermal exergy efficiency is decreased for several industries considerably. For the metal processing industries, which had the highest thermal site efficiencies, the system one is considerably reduced. Within the food and chemical industry, no considerable reductions are found as most of the thermal energy originates from natural gas and other fuels. Figure 9 shows a comparison of the total site

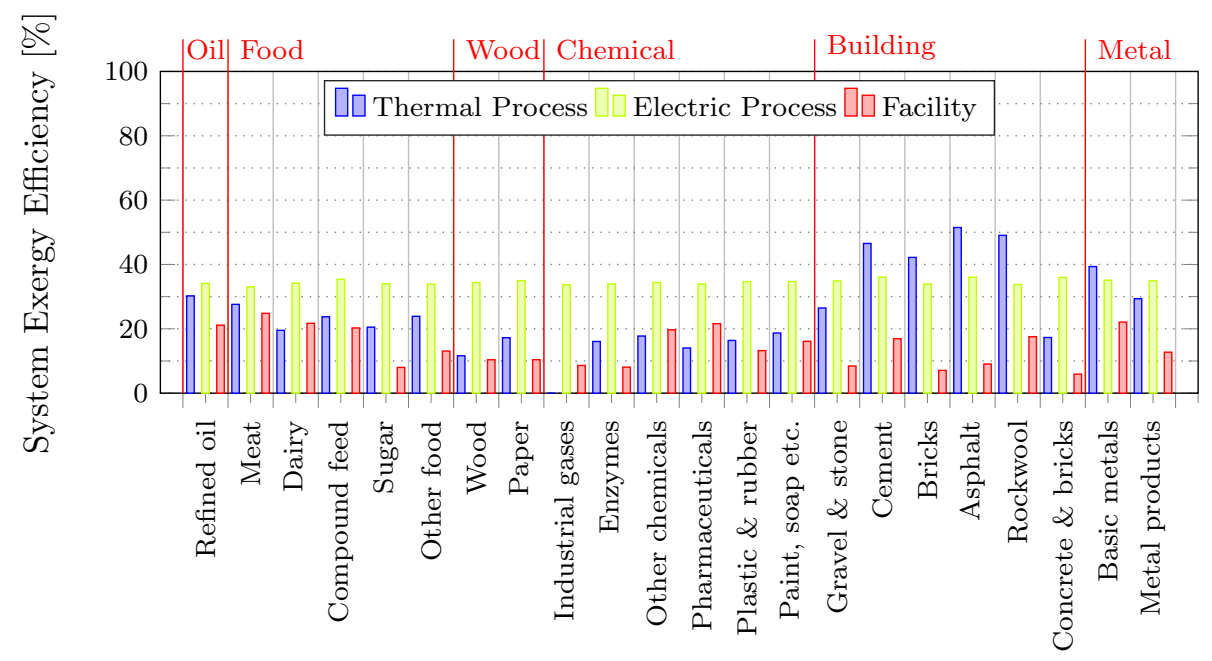

Figure 8: System exergy efficiencies for thermal and electric processes and facility within the industry sector (2012).

and total system exergy efficiency, taking into account all heating and electric processes. The production of industrial gases has the highest site efficiency but the system efficiency is only half, as this industry uses primarily electric energy. Similar differences in the efficiency are found for food and metal industry, where the production relies on electricity and district heat. In contrary, industries such as oil refinery, sugar, cement and brick production have only small differences in the site and system efficiency. By using the system exergy efficiency and thereby extending the system boundaries, it is possible to account for all the losses occurring in the industry. These system exergy efficiencies are important indicators for a system analysis, and can be used to assess the most optimum energy sources for the production. For some industries, e.g. production of industrial gasses, the possible actions are limited as there is no alternative to the use of electricity in the processes.

Exergy loss and destruction. The analysis of exergy loss and destruction shows the recovery potentials in the industries. This is possible as the exergy content of the stream describes the maximum work which can be retrieved. Figure 10 


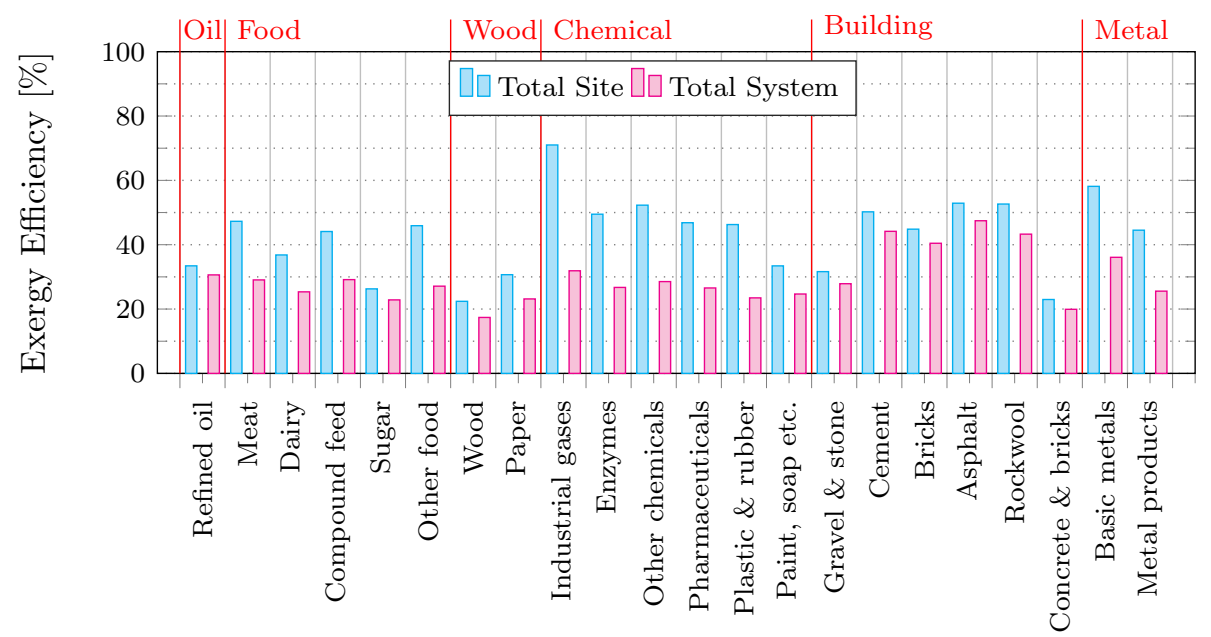

Figure 9: Total site and system exergy efficiencies for exergy use in processes and facilities within the different industry sector (2012).

presents the share of exergy loss and destruction of the total site exergy input for the thermal conversion in the industry. The production of building materials has the largest potential, with the exergy loss being up to $10 \%$ of the total thermal input. Significant potentials of above $5 \%$ are also found in the food, wood, paper and chemical industry. In Figure 11 the exergy loss and system exergy loss for each industry is shown for the thermal processes and machine drives. The industries with the highest energy input, also have the highest exergy loss on site. However industries with a high electric energy consumption, almost reach the same total exergy losses, such as the production of meat and dairy products (sector 3 and 4). In total, approximately $3800 \mathrm{TJ}$ of exergy are lost from thermal processes within the industry and an additional $200 \mathrm{TJ}$ in the supply of room heating. The production of cement and the refinery of oil have together an accumulated exergy loss of $1600 \mathrm{TJ}$ from thermal processes. In these industries possibilities of more process integration and the export of heat should be considered, by implementing heat recovery systems. For most industries, the majority of the exergy loss is associated with the electricity use in machines. Only the production of metal and rubber (industry no. 14) has a considerable exergy loss for thermal processes, due to the use of electricity for heating. The overall exergy flows for thermal processes in the industry are shown in Figure 12 and confirm the previous findings. Only a small fraction of the total exergy destruction $(7 \%)$ results from the utility sector. The majority of the lost exergy originates from the production of building material and oil. In total, an exergy loss for thermal processes of almost $5000 \mathrm{TJ}$ is found when including the losses associated with the utilities. The system losses can be reduced by increasing the share of wind energy and the production of district heat. The exergy losses, as found in this section, describe the potential of exploiting the energy associated 


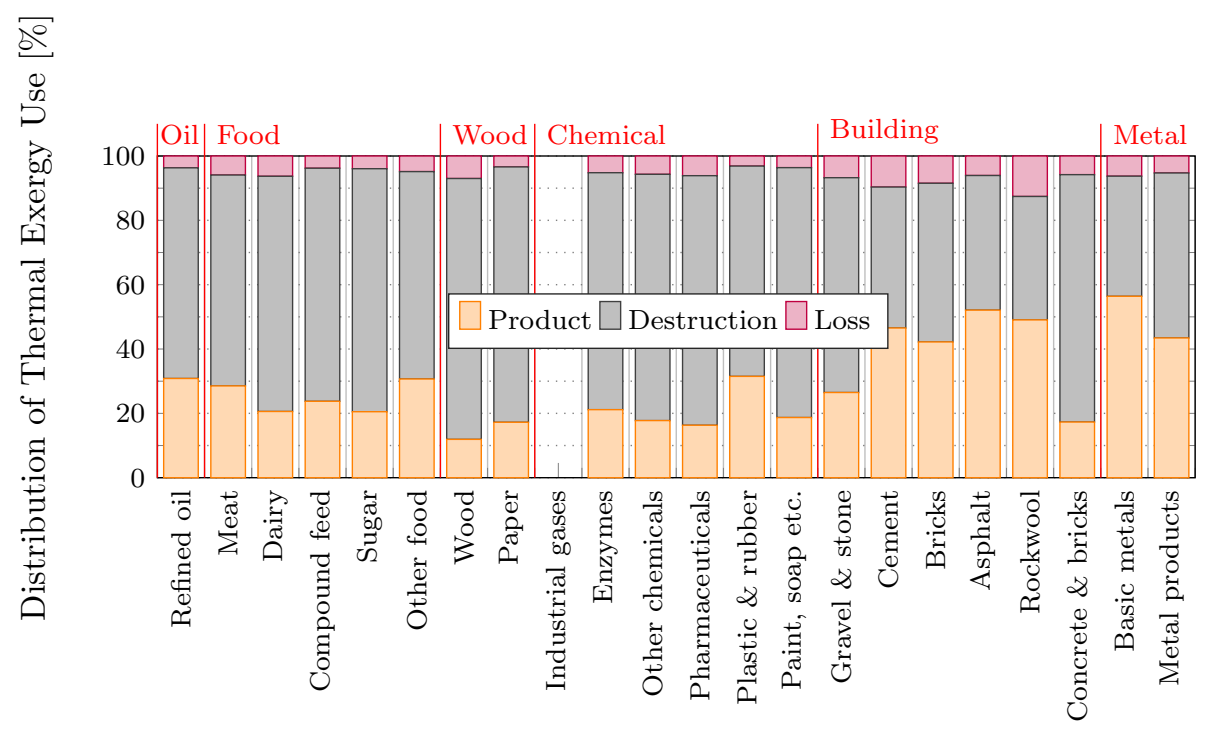

Figure 10: Distribution of exergy for process and facility heating within the industry sector (2012).

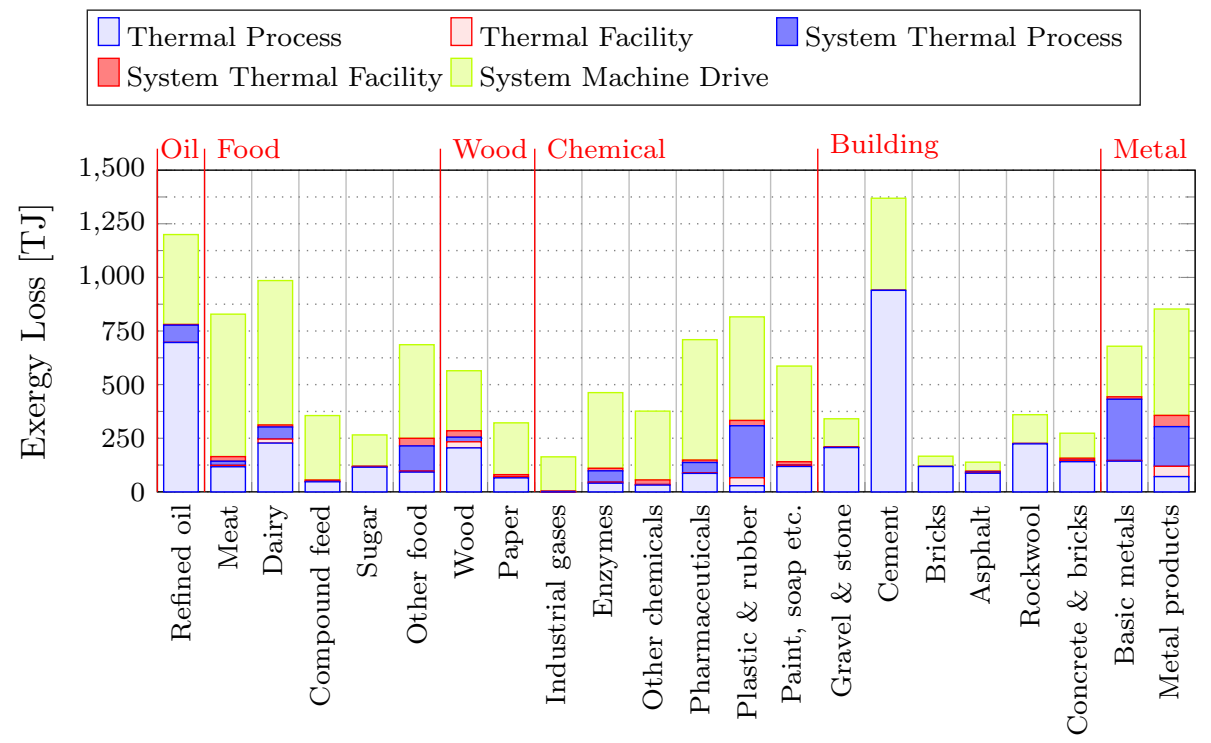

Figure 11: Exergy loss divided by source for the different industrial sectors (2012).

with the stream currently discharged into the environment. These losses can be reduced by further process integration and waste heat recovery. For example, the implementation of heat pumps and organic Rankine cycles would result in 


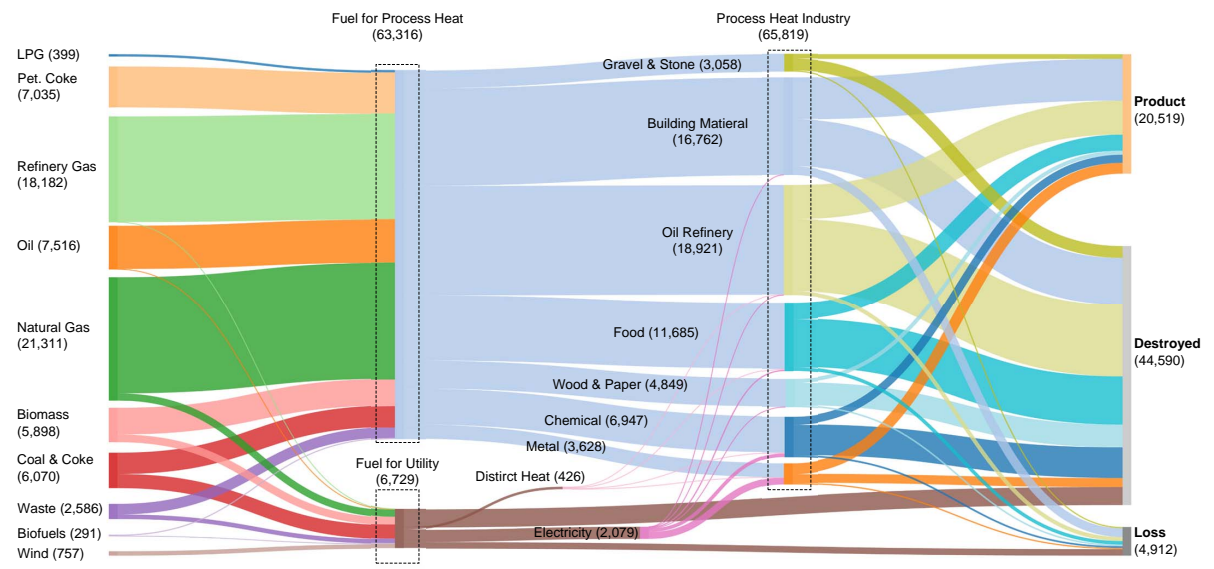

Figure 12: Exergy loss divided by source for the different industrial sectors (2012).

the conversion of low-temperature heat into district heating and electricity.

Comparison of 2006 and 2012. A comparison of changes in efficiency between 2006 and 2012 for the main industry groups is shown in Figure 13. On a site level the efficiency increased for most industries by up to $3.9 \%$-points. A considerable reduction in efficiency is seen for the wood processing industry, which is caused by structural changes causing a decrease in electricity consumption for machine drives. This causes a higher weighting of the thermal processes, which have a lower efficiency. Using the system exergy efficiency, also the wood industry had an increase in efficiency, as the losses from electricity use are smaller. Considering the overall efficiencies for the Danish industry as a whole, a clear

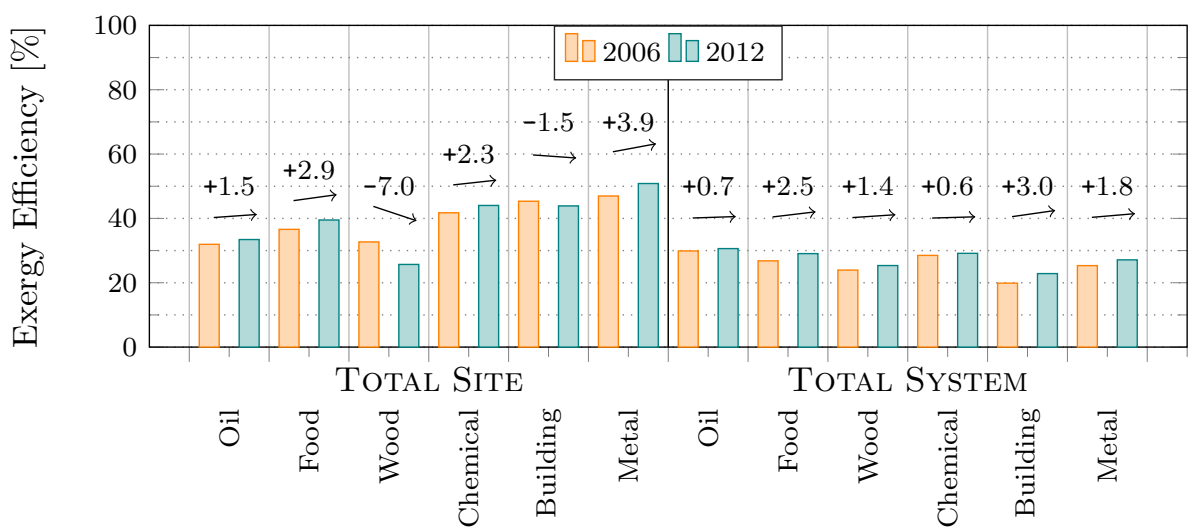

Figure 13: Change in the total site and total system exergy efficiency for industry groups between 2006 and 2012 .

improvement can be found from the first law analysis for almost all efficiencies, 
as can be seen in Table 4. For the exergy analysis, the efficiency of the thermal processes has decreased, whereby the total exergy efficiency has increased slightly. This increase is a result of the improved use of electricity in the facilities, which has a strong weight on the result due to its high exergetic value.

Table 4: Total industry efficiency of the Danish industrial sector for 2012 and 2006, expressed in \%. The terms SiEX, SyEX, SiEN and SyEN stand for site exergy, system exergy, site energy and system energy.

\begin{tabular}{lrrrrrrrr}
\hline Efficiency [\%] & \multicolumn{2}{c}{ SiEX } & \multicolumn{2}{c}{ SyEX } & \multicolumn{2}{c}{ SiEN } & \multicolumn{2}{c}{ SyEN } \\
& 2012 & 2006 & 2012 & 2006 & 2012 & 2006 & 2012 & 2006 \\
\hline Thermal Processes & 31.2 & 32.6 & 29.3 & 30.6 & 80.3 & 78.8 & 77.8 & 75.8 \\
Thermal Facility & 3.6 & 3.5 & 2.7 & 2.7 & 90.9 & 90.3 & 78.1 & 73.2 \\
Electric Processes & 81.4 & 81.6 & 34.0 & 32.4 & 81.4 & 81.6 & 57.2 & 47.3 \\
Electric Facility & 64.3 & 60.3 & 27.2 & 23.9 & 64.3 & 60.3 & 45.2 & 34.9 \\
Total & 39.7 & 39.7 & 29.6 & 28.8 & 80.6 & 79.7 & 71.8 & 66.4 \\
\hline
\end{tabular}

\section{Discussion}

Uncertainties and Limitations. This sectorial analysis is subject to some uncertainties in the used data and applied method, which are discussed in the following. The distribution of the fuels amongst the categories is based on the Danish Energy Agency[2008b,2015], where detailed information of the energy consumptions of the main companies of each sector was used. Where no information was available, processes representing the sector and assumptions were undertaken. These distributions are representative for homogeneous industry sectors, but for sectors such as (7.) Other food products and (12.) Other chemicals, assumptions and generalisations had to be made. The same applies for the process temperatures and their distribution. In particular, for the production of pharmaceutical products, enzymes and other chemicals, insufficient information was present to create a precise end-use model. The implications of the resulting uncertainties are small for the energy efficiencies, as the process temperatures in these industries are mainly below $125^{\circ} \mathrm{C}$, for which the direct heating efficiency was chosen to be between $85 \%$ and $100 \%$. The exergy efficiency however, is related to the process temperature and changes with a varying fuel distribution amongst the process temperatures. For the most critical sectors, the temperatures are nevertheless in a similar range of $50{ }^{\circ} \mathrm{C}$ to $125^{\circ} \mathrm{C}$ and do not include any high temperature processes.

The data of 2006 and 2012 are not directly comparable for all sectors and some assumptions had to be made. Statistics Denmark has reorganised the industry classification in 2008, and, as a result, some industries were allocated to new sectors. Furthermore, structural changes within some sectors and different economic developments were not taken into account. The production of combined heat and power within the industry is neglected in this study, as insufficient data 
is available. The calculation of the exergy losses is nonetheless not impacted by these limitations, as the basic data does not include the fuels for heat and power production on the industrial site.

For the energy in electricity and district heat, the allocation of primary energy was based on the product distribution. As in the case of the first law analysis, the value of the products is identical, the fuel consumption in the product is the same. For exergy, the allocation of the input to the utility sector was distributed based on the exergy content of the products. This results in a higher allocation of the input to the electricity production, than in the energy analysis. However, as more exergy is destroyed in the production of district heat, the specific exergy destruction per unit of exergy is higher for district heating.

Method and Results. The total process heating efficiency for the Danish industry is in the same range as for other countries, amongst others Iran [Sanaei et al.,2012], Saudi Arabia [Dincer et al.,2003] and South Africa [Oladiran and Meyer,2007], where exergetic process heating efficiencies of around $30 \%$ were found. The energy efficiency for both process heating and the total site are however higher in this study, compared to values between $50 \%$ and $70 \%$ in the other studies. This is primarily a result of the higher direct process heating efficiencies chosen in this study. The same applies on a sectorial level, where for comparable industries similar exergetic efficiencies are found but higher ones for energy.

Other studies have used large definitions of industrial sectors, such as Chemical \& Petroleum [Oladiran and Meyer,2007]. The disaggregation of this sector into seven sub-sectors, as done in this study, shows that efficiencies can vary considerably. The production of industrial gases reaches a total site exergetic efficiency of $70 \%$, whereby oil refineries are below $35 \%$. The inclusion of inefficiencies occuring in the utility sector, allow a more valid comparison of industrial sectors and the use of fuels with electricity and district heat. Based on the system efficiency, continuous efforts should be made to avoid electric heating if the electricity originates from other sources than wind power.

By using the method applied in this study, a complete comparison of industries and countries is possible, also taking into account the efficiency of the national utility system. This allows to track the development of the industries over time and to target efficiency and waste heat recovery measures on a national level. The high level of detail in the model makes it further possible to find inefficiencies on a process level and to quantify the real recovery potential.

\section{Conclusion}

This paper analyses the energy and exergy efficiency, as well as the destroyed and lost exergy, of 22 industrial sectors in Denmark for the years 2006 and 2012. By using the distribution of fuels and temperature levels for different processes within the sectors, a detailed end-use model for the thermal energy use for individual industries is created. The utility sector is included in a further 
approach to find the system exergy and energy flows, for electricity and district heat supplied to the industry.

From the case study, the main conclusions are that the share of lost exergy found in the thermal processes within the industry suggests that there are large potentials for waste heat recovery. The lost exergy from the central production of heat and power is considerable higher than the losses on-site, as the use of electric energy for machines is included in the losses. In 2012 for individual industries, the thermal process efficiencies range from $12 \%$ to $56 \%$, where industries with high temperature processes such as cement and metal production achieve the highest efficiencies. The energy efficiency is between $63 \%$ and $90 \%$, the less efficient industries are characterised by high-temperature processes, and the most efficient ones are namely the food, paper and chemical industry. On an industry level, the total exergy efficiency is approximately $40 \%$ with the system exergy being around $10 \%$ points lower. A comparison of the years 2006 and 2012 shows no remarkable improvements on an exergetic level, but the energy efficiency is considerably improved. It is suggested that future actions towards energy efficiency measures in the industry, target the high temperature processes, where large quantities of energy are recoverable. Furthermore, the use of district heat and heat pumps for low temperature processes would improve the site efficiencies. Although the share of district heat and heat pumps has increased between 2006 and 2012, the improvement is not yet notable in the total efficiency. Moreover, this paper gives a basis for future analyses of the industrial sectors, and the application of the method is described in details. The importance of including the system efficiencies was shown. The additional information which can be obtained by disaggregating sectors and determining exergy losses and destruction, has shown to be useful when locating excess heat potentials.

\section{Acknowledgments}

The funding from the Danish Council for Strategic Research in Sustainable Energy and Environment is acknowledged. The authors would like to thank the energy consultancy firm Viegand Maagøe A/S for sharing their expertise in the industry sector in Denmark.

\section{References}

Danish Energy Agency. Energy Policy Toolkit on Energy Efficiency in Industries: Experiences from Denmark. Tech. Rep.; Low Carbon Transition Unit; 2014a. URL: http://www.ens.dk/en/policy/Global-cooperation/ information-materials/.

Hammond, G.P.. Industrial energy analysis, thermodynamics and sustainability. Applied Energy 2007;84(7-8):675-700.

Hammond, G.P., Norman, J.B.. Heat recovery opportunities in UK industry. Applied Energy 2014;116:387-397. 
Ammar, Y., Joyce, S., Norman, R., Wang, Y., Roskilly, A.P.. Low grade thermal energy sources and uses from the process industry in the UK. Applied Energy 2012;89(1):3-20.

Reistad, G.M.. Available energy conversion and utilization in the United States. J Eng Power Trans ASME 1975;97 Ser A(3):429 - 434.

Rosen, M.. Evaluation of energy utilization efficiency in Canada using energy and exergy analyses. Energy 1992;17(4):339-350.

Wall, G.. Exergy use in the Swedish society 1994. In: Thermodynamic Analysis and Improvement of Energy Systems,. ISBN 7-5062-3264-Z; 1997, p. 403-413.

Hammond, G.P., Stapleton, A.J.. Exergy analysis of the United Kingdom energy system. Proceedings of the Institution of Mechanical Engineers, Part A: Journal of Power and Energy 2001;215:141-162.

Utlu, Z., Hepbasli, A.. Turkey's sectoral energy and exergy analysis between 1999 and 2000. International Journal of Energy Research 2004;28(13):11771196.

Dincer, I., Hussain, M.M., Al-Zaharnah, I.. Analysis of sectoral energy and exergy use of Saudi Arabia. International Journal of Energy Research 2004a;28(3):205-243.

Ertesvåg, I.S.. Energy, exergy, and extended-exergy analysis of the Norwegian society 2000. Energy 2005;30(1):649-675.

Hepbasli, A.. Modeling of Sectoral Energy and Exergy Utilization. Energy Sources 2005;27(January 2015):903-912.

Utlu, Z., Hepbasli, A.. A review on analyzing and evaluating the energy utilization efficiency of countries. Renewable and Sustainable Energy Reviews 2007;11(1):1-29.

Dincer, I., Hussain, M.M., Al-Zaharnah, I.. Energy and Exergy Use in Residential Sector of Saudi Arabia. Energy Sources 2004b;26(13):1239-1252.

Liu, Y., Li, Y., Wang, D., Liu, J.. Energy and exergy utilizations of the Chinese urban residential sector. Energy Conversion and Management 2014;86:634-643.

Motasemi, F., Afzal, M.T., Salema, A.A., Moghavvemi, M., Shekarchian, M., Zarifi, F., et al. Energy and exergy utilization efficiencies and emission performance of Canadian transportation sector, 1990-2035. Energy 2014;64:355366 .

Al-Ghandoor, A., Phelan, P.E., Villalobos, R., Jaber, J.O.. Energy and exergy utilizations of the U.S. manufacturing sector. Energy 2010;35(7):3048-3065. 
Sanaei, S.M., Furubayashi, T., Nakata, T.. Assessment of energy utilization in Iran's industrial sector using energy and exergy analysis method. Applied Thermal Engineering 2012;36:472-481.

Dincer, I., Hussain, M.M., Al-Zaharnah, I.. Energy and exergy use in the industrial sector of Saudi Arabia. Proceedings of the Institution of Mechanical Engineers, Part A: Journal of Power and Energy 2003;217:481-492.

Oladiran, M., Meyer, J.. Energy and exergy analyses of energy consumptions in the industrial sector in South Africa. Applied Energy 2007;84(10):1056-1067.

Bühler, F., Nguyen, T.V., Elmegaard, B.. Energy and Exergy Analysis of the Danish Industry Sector. In: Proceedings of the 10th Conference on Sustainable Development of Energy, Water and Environment Systems; vol. SDEWES2015.0772. Dubrovnik, Coratia; 2015, p. 1-21.

Soundararajan, K., Ho, H.K., Su, B.. Sankey diagram framework for energy and exergy flows. Applied Energy 2014;136:1035-1042.

Statistics Denmark. ENE2HA: Energy Account in common units (detailed table) by use and type of energy. 2015. URL: http://www.dst.dk/en/ Statistik/nyt/relateret. aspx?psi=1190.

Danish Energy Agency. Kortlægning af erhvervslivets energiforbrug. Tech. Rep.; Danish Energy Agency; 2008a. URL: http://www.ens.dk/ forbrug-besparelser/; [In Danish].

Danish Energy Agency. Energy Statistics 2012. Tech. Rep.; Danish Energy Agency; 2014b. URL: http://www.ens.dk/en/info/facts-figures/.

Danish Energy Agency. Energy Statistics 2006. Tech. Rep.; Danish Energy Agency; 2008b. URL: http://www.ens.dk/info/publikation.

Bejan, A., Tsatsaronis, G., Moran, M.. Thermal design and optimization. New York: Wiley-Interscience; 1996. ISBN 9780471584674.

Szargut, J.. Chemical exergies of the elements. Applied Energy 1989;32(4):269286.

Ertesvåg, I.S.. Sensitivity of chemical exergy for atmospheric gases and gaseous fuels to variations in ambient conditions. Energy Conversion and Management 2007;48(7):1983-1995.

Utlu, Z., Hepbasli, A.. Energetic and exergetic assessment of the industrial sector at varying dead (reference) state temperatures: A review with an illustrative example. Renewable and Sustainable Energy Reviews 2008;12:12771301.

Danish Energy Agency. Kortlægning af energiforbrug i virksomheder. Tech. Rep.; Danish Energy Agency; 2015. URL: http://www.ens.dk/ forbrug-besparelser/; [In Danish]. 
European Commission. Best Available Techniques Reference Document (BREFs). 2015. URL: eippcb.jrc.ec.europa.eu/reference.

Graz University of Technology. Matrix for Industrial Process Indicators. 2015. URL: wiki zero-emissions .at/.

U.S. Environmental Protection Agency. Compilation of Air Pollutant Emission Factors, AP-42, 5th ed. 2015. URL: www.epa.gov/ttnchie1/ap42/.

Viegand Maagøe A/S. Analyse af muligheder for bedre udnyttelse af overskudsvarme fra industrien. Tech. Rep.; Viegand Maagøe A/S; 2013. URL: http://www.ens.dk/info/nyheder/nyhedsarkiv/ industrien-kan-tjene-penge-paa-overskudsvarmen; [In Danish].

U.S. Department of Energy. Waste Heat Recovery: Technology and Opportunities in U.S. Industry. Tech. Rep.; U.S. Department of Energy; 2008. URL: http://www1 . eere . energy.gov/manufacturing/intensiveprocesses/.

Technical University of Denmark. Industrial Energy Mapping. Tech. Rep.; 2015.

Dansk Energi. Den store blå om Systemoptimering. Tech. Rep.; Dansk Energi; 2015. URL: http://www.elforsk.dk/Den\%20lille_store\%20blaa.aspx; [In Danish].

Nag, P.K.. Power Plant Engineering. New Delhi: Tata McGraw-Hill Education; 2002 .

Szargut, J., Zibik, A., Stanek, W.. Depletion of the non-renewable natural exergy resources as a measure of the ecological cost. Energy Conversion and Management 2002;43(9-12):1149-1163.

Granovskii, M., Dincer, I., Rosen, M.a.. Exergetic life cycle assessment of hydrogen production from renewables. Journal of Power Sources 2007;167(2):461-471.

Cornelissen, R.L., Hirs, G.G.. The value of the exergetic life cycle assessment besides the LCA. Energy Conversion and Management 2002;43(9-12):14171424 .

Stougie, L., Kooi, H.J.V.D.. Exergy and sustainability. International Journal of Exergy 2012;11(4):508. 